\title{
THE PHYSICAL AND CHEMICAL PROPERTIES OF CAMEL'S AND SHEEP'S MILK IN QENA GOVERNORATE Hamad, M. N. E. ${ }^{1}$ and A. A. Baiomy ${ }^{2}$ 1-Food Science and Dairy Department, Faculty of Agriculture, "Qena", South Valley University. \\ 2-Animal production Department, Faculty of Agriculture, "Qena", South Vally University.
}

\begin{abstract}
This study was carried out to evaluate some physical properties and chemical composition of some lactating animals in Qena governorate, Egypt. Composite samples of camels' and sheep's (Ossimi breed) milks were collected from twelve individual farms in Qena. Physical parameter used to monitor the quality of milk samples was specific gravity. The samples were also analysed for the gross chemical composition, fatty acids composition of milk fat and minerals contents. Sheep's milk has higher specific gravity than Camel milk and the contents of fat, protein, lactose, ash and total solids in sheep's milk were significantly $(p<0.05)$ higher than camel milk.

Fatty acid composition of camel milk fat differed significantly $(p<0.05)$ from that of sheep "ossimi" milk fat analysed, it contained higher content of (C16:0, C16:1, C18:0 and C18:2) than sheep "ossimi" milk fat, while, sheep "ossimi" milk fat were significantly $(p<0.05)$ higher of $(C 6: 0-C 12: 0)$ and $(C 18: 1)$ than camel milk fats.

The levels of $\mathrm{Ca}, \mathrm{P}$ and $\mathrm{K}$ in the sheep "ossimi" milk ash were significantly higher $(P<0.05)$ than those in the camel milk ash, while, the level of $\mathrm{Na}$ and $\mathrm{Fe}$ in the camel milk ash were significantly higher $(P<0.05)$ than those in the sheep "ossimi" milks ash.
\end{abstract}

Keywords: Camel, sheep, milk, physical, chemical composition, fatty acids, minerals.

\section{INTRODUCTION}

Milk and dairy products are part of a healthy diet which, besides cow's milk, consists of sheep's, goat's and buffalo's milk (Hinrichs, 2004). Although the milk composition of dairy animals has been widely studied throughout the world, the literature data mainly concerns cow milk, which represents $85 \%$ of the milk consumed in the world and to a lesser extent, goat and sheep milk. Studies on other dairy animals (buffalo, yak, mare, and camel) are rather scarce, in spite of their nutritional interest. In this context, camel milk needs further investigation. There are only a few references on camel milk, which concern production or composition aspects (Farah, 1993). Camel milk is an important component of human diet in many parts of the world. It considered as an important source of protein for the people living in the arid lands of the world. Camel's milk is characterized with the high content of potassium, magnesium, iron, copper, manganese, sodium and with the lower content of lactose than cow's milk (Gorban \& Izzeldin, 1997 and Hashim, 2002). Historically, camel's milk has been used for a number of medical problems (Omer \& Eltinay, 2009), as it has anti-cancer (Magjeed, 2005), hypo-allergic (Shabo et al., 2005) and anti-diabetic (Agrawal et al., 2003) properties. 
Sheep's milk is generally characterized by its high total solids, fat and calcium content. The total solids of sheep's milk is one fold and half of that of cow's milk solids, while fat and proteins recorded are two folds (Miocinovic et al., 2007). Although sheep milk is an excellent source of nutrients in human nutrition a sit is superior to cow milk in the supply of all ten essential amino acids, calcium and phosphorus (Jandal, 1996), the nutritive value of sheep milk has not received much research attention (Haenlein, 2001).

This study is a trial to investigate the nutritional value of sheep's and camel's milk determined as compositional quality as well as fatty acid and mineral content of lactating animals in Qena government.

\section{MATERIALS AND METHODS}

\section{Materials:}

Milk samples:

Composite milk samples $(500 \mathrm{ml})$ of Egyptian sheep's "ossimi" and camel's at the peak of lactation period were collected once a week from twelve farms in Qena governorate during the period from January till April 2009. The composite milk samples were morning and evening milk.

\section{Methods:}

The collected milk samples were analysed physically and chemically at Dairy Technology Laboratory of Animal Production Experimental Farm, Faculty of Agriculture, South Valley University, Qena, and the following indices were measured:-

\section{Chemical and physical analysis:}

The $\mathrm{pH}$ was measured using digital $\mathrm{pH}$ meter (Model PTI-6, Aqua Chemical Co., Devon, U.K.) equipped with a combined glass electrode, specific gravity using lactometer as described by (Aggarwala \& Sharma, 1961). The fat content was determined by the Gerber method according to (James, 1995), total solids, ash and protein contents according to (A.O.A.C., 1995) methods, and the solids not fat (SNF) and lactose contents were determined by difference.

- SNF content $=$ TS $\%$ - Fat $\% \quad \cdot$ Lactose $\%=$ TS $\%-($ Fat $\%+$ Protein $\%+$ Ash $\%)$

\section{Mineral analysis:}

The minerals were determined as follow; sodium, potassium and calcium contents were determined often, by ashing method using flame photometer (Corning 410, Sherwood Scientific Limited, UK) as described by (Kirk \& Sawyer, 1991), inorganic phosphorus by the colorimetric method as described by (Fiske \& Subbarow, 1925), iron and lead by absorption spectrophotometer (Perkins Elmer Instrument Model 2380, Perkin Elmer, Michigan, USA) as described by (A.O.A.C., 1995).

\section{Fatty acid analysis:}

The fatty acids of milk fat were determined by Gas-Liquid Chromatography (GLC) according to the procedure described by (Ackman, 
1972). The fatty acid methyl esters were analyzed by using PYE-Unicam Model P V4550 gas-Liquid Chromatography with dual-flame ionization detector.

\section{Statistical analysis:}

Data were statistically analyzed according to the General Linear Model (G.L.M) and the differences between means were detected by Duncan`s Multiple Range Test (S.A.S., 1998).

\section{RESULTS AND DISCUSSION}

\section{Specific gravity and $\mathrm{pH}$ values:}

Results in (Table 1) showed that the specific gravity of camel's milk was slightly less than that of sheep's "ossimi" milk. These results agree with (Shamsia, 2009). pH values of both types of milk were similar. These results agree with (Khaskheli et al., 2005 and Omer \& Eltinay, 2009).

Table (1): Specific gravity and $\mathrm{pH}$ values of camel's and sheep's "ossimi" milk samples collected from different sources in Qena. (Mean \pm Se).

\begin{tabular}{|c|l|l|l|l|l|l|}
\hline \multirow{2}{*}{ Item } & \multicolumn{3}{|c|}{ Camel } & \multicolumn{3}{c|}{ Sheep "Ossimi" } \\
\cline { 2 - 7 } & \multicolumn{1}{|c|}{ Mean } & Min. & Max. & \multicolumn{1}{c|}{ Mean } & Min. & Max. \\
\hline S.G. & $1.031 \pm 0.0007$ & 1.029 & 1.032 & $1.0365 \pm 0.0009$ & 1.035 & 1.039 \\
\hline pH value & $6.59 \pm 0.185$ & 6.42 & 6.76 & $6.6 \pm 0.179$ & 6.44 & 6.76 \\
\hline
\end{tabular}

Min. : minimum, Max. : maximum, S.G.: Specific gravity

\section{Chemical composition:}

The chemical composition of camel and sheep milks is shown in table (2). The results indicated to the great differences betweens the milks of the two animals. Sheep's milk appears as a rich source of milk components compared to the camel's milk.

Table (2): Chemical composition of camel's and sheep's "ossimi" milk samples collected from different sources in Qena. (Mean \pm Se).

\begin{tabular}{|l|c|c|}
\hline \multicolumn{1}{|c|}{ Item } & Camel & Sheep "Ossimi" \\
\cline { 2 - 3 } & Mean & Mean \\
\hline Fat (F. \%) & $4.4 \pm 0.31^{\mathrm{b}}$ & $7.26 \pm 0.13^{\mathrm{a}}$ \\
\hline Protein (P. \%) & $4 \pm 0.22^{\mathrm{b}}$ & $5.05 \pm 0.27^{\mathrm{a}}$ \\
\hline Lactose (L. \%) & $3.94 \pm 0.12^{\mathrm{b}}$ & $4.8 \pm 0.18^{\mathrm{a}}$ \\
\hline (Ash \%) & $0.7 \pm 0.21^{\mathrm{b}}$ & $0.89 \pm 0.14^{\mathrm{a}}$ \\
\hline Solids Not Fat (SNF \%) & $9.3 \pm 0.25^{\mathrm{b}}$ & $10.74 \pm 0.23^{\mathrm{a}}$ \\
\hline Total Solids (TS \%) & $14.00 \pm 0.27^{\mathrm{b}}$ & $18 \pm 0.29^{\mathrm{a}}$ \\
\hline Water (W \%) & $86 \pm 1.04^{\mathrm{a}}$ & $82 \pm 0.89^{\mathrm{b}}$ \\
\hline
\end{tabular}

and $b$ Means in the same row followed by different letters are significantly different $(p<0.05)$.

The average total solids of sheep's milk were $18 \%$ compared to $14 \%$ for camel's milk. These results are in agreement with (Hassan, 1994) who found that the total solids of Ossimi sheep's milk ranged between 17.66 and 
$18.16 \%$. Omer \& Eltinay (2009) confirmed the low total solid contents of camel's milk; they mentioned 85.30 to $87.61 \%$ moisture for camel's milk.

Milk components of fat, protein, ash and lactose are coincided well with the solid content of the two milks. Sheep's given milk richer in fat, protein and ash compared to camel's milk. The average fat, protein, ash and lactose content of sheep's milk were: $7.26 \%, 5.05 \%, 0.89 \%$ and $4.8 \%$, respectively, while the corresponding values for camel's milk are: $4.4 \%, 4 \%, 0.7 \%$ and $3.94 \%$, respectively.

The high protein content of Ossimi sheep's milk was in agreement with (Hassan, 1994), but it is lower than that reported by EL-Saied et al., (1998) who reported protein in range of 5.63 to $5.91 \%$.

The author explained the low ash content of camel's milk to the free grazing of camel on bushes or plant grown at saline soils. Also, the results mentioned to the low level of lactose in camel's milk compared to the content of lactose in sheep's milk. The low level of lactose in camel's milk was mentioned by other workers (Ahmed, 1990 and Khaskheli, et al., 2005). Hassan et al., (1987) found that the lactose content of Egyptian camel's milk was in range of 3.4 to $5.6 \%$.

Generally, the physiological differences of the animal, stage of lactation and some common factors such as season, feed, breed, time and sequence of milking could be responsible for the differences in concentration of protein, fat, lactose, ash and consequently dry matter, which were found to be higher in sheep's milk than in camel's milk.

\section{Fatty acid composition of the milk fat:}

The profile of fatty acids compositions of Ossimi milk fat and camel milk fat is shown in Table (3) marked differences were recorded. The Ossimi milk fat contained high level of saturated fatty acids $(71.87 \%)$, the majority of which are the short chain fatty acid (C6:0 - C12:0). On the other hand the medium chain saturated fatty acids $(\mathrm{C} 14: 0, \mathrm{C} 18: 0)$ represented high percentage in camel milk fat compared to its contents in Ossimi milk fat.

The results in Table (3) also, mentioned to the high content of unsaturated fatty acids in camel milk fat compared to its content in Ossimi milk fat (35.9 Vs 28.13), the more pronounced unsaturated fatty acids in camel milk are $\mathrm{C} 16: 1$ and $\mathrm{C} 18: 2$ while the fatty acid C18:1 is the more pronounced fatty acid in Ossimi milk fat.

The fatty acid composition of camel's milk fat in the present study is consistent with that reported by (El-Agamy, 2006). The ratio of saturated/unsaturated acid was more favorable in sheep's milk compared with camels' milk and otherwise higher values were found for the C6:0, C8:0, C10:0 and C12:0 fatty acids than that reported by (Gomez-Cortes et al., 2008) in ewe's milk. These results were similar to those obtained by (Konuspayeva et al., 2008) they found that the fatty acid composition of camel milk fat differed from mammalian fats by its high content of the longchain fatty acids C14:0, C16:0 and C18:0. 
Table (3): The fatty acid composition of milk fat samples from different regions of Qena. (Mean $\pm \mathrm{SE}$ ).

\begin{tabular}{|l|c|c|}
\hline \multicolumn{1}{|c|}{ Fatty acids } & Camel & Sheep "Ossimi" \\
\hline C6:0 & $0.54 \pm 0.31^{\mathrm{b}}$ & $2.89 \pm 0.24^{\mathrm{a}}$ \\
\hline C8:0 & $0.67 \pm 0.17^{\mathrm{b}}$ & $2.95 \pm 0.18^{\mathrm{a}}$ \\
\hline C10:0 & $0.46 \pm 0.24^{\mathrm{b}}$ & $9.55 \pm 0.23^{\mathrm{a}}$ \\
\hline C12:0 & $1.23 \pm 0.11^{\mathrm{b}}$ & $5.4 \pm 0.27^{\mathrm{a}}$ \\
\hline Unknown & $0.89 \pm 0.27^{\mathrm{b}}$ & $2.02 \pm 0.21^{\mathrm{a}}$ \\
\hline C14:0 & $13.26 \pm 0.59^{\mathrm{a}}$ & $11.8 \pm 0.47^{\mathrm{a}}$ \\
\hline C14:1 & $1.81 \pm 0.14^{\mathrm{a}}$ & $1.21 \pm 0.11^{\mathrm{b}}$ \\
\hline C15:0 & $1.27 \pm 0.14^{\mathrm{b}}$ & $2.86 \pm 0.41^{\mathrm{a}}$ \\
\hline C16:0 & $33.15 \pm 0.44^{\mathrm{a}}$ & $25.4 \pm 0.51^{\mathrm{b}}$ \\
\hline C16:1 & $11.55 \pm 0.14^{\mathrm{a}}$ & $3.4 \pm 0.14^{\mathrm{b}}$ \\
\hline C18:0 & $12.43 \pm 1.01^{\mathrm{a}}$ & $9.00 \pm 1.04^{\mathrm{b}}$ \\
\hline C18.1 & $17.46 \pm 0.55^{\mathrm{b}}$ & $20.31 \pm 0.36^{\mathrm{a}}$ \\
\hline C18.2 & $4.04 \pm 0.31^{\mathrm{a}}$ & $2.1 \pm 0.29^{\mathrm{b}}$ \\
\hline C18.3 & $1.04 \pm 0.27^{\mathrm{a}}$ & $1.11 \pm 0.24^{\mathrm{a}}$ \\
\hline Total fatty acids\% & 99.80 & 100 \\
\hline Saturated \% & $64.1 \pm 0.52^{\mathrm{b}}$ & $71.87 \pm 0.49^{\mathrm{a}}$ \\
\hline Unsaturated\% & $35.9 \pm 0.54^{\mathrm{a}}$ & $28.13 \pm 0.53^{\mathrm{b}}$ \\
\hline Saturated : Unsaturated\% & $1.78: 1$ & $2.55: 1$ \\
\hline
\end{tabular}

$a$ and $b$ Means in the same row followed by different letters are significantly different $(p<0.05)$.

\section{The mineral content of milk samples:}

The mineral content of camel milk expressed as ash ranges from 0.6 to $0.8 \%$ (Hassan et al., 1987). The ash contents in camel milk are lower than in sheep milk (Table 2). This may be due to the effect of feeding as well as the types of fodders grazed by camels (Sendra, et al., 2002).

Tables (4): Mineral contents of camel's and sheep's "Ossimi" milk in Qena (p.p.m.). (Mean \pm SE).

\begin{tabular}{|l|c|c|}
\hline \multicolumn{1}{|c|}{ mineral contents } & Camel & Sheep "ossimi" \\
\hline $\mathbf{C a}$ & $1198 \pm 23.65^{\mathrm{b}}$ & $1883 \pm 26.70^{\mathrm{a}}$ \\
\hline $\mathbf{P}$ & $597 \pm 23.41^{\mathrm{b}}$ & $890 \pm 25.21^{\mathrm{a}}$ \\
\hline $\mathrm{Na}$ & $664 \pm 16.4^{\mathrm{a}}$ & $530 \pm 21.6^{\mathrm{b}}$ \\
\hline $\mathbf{K}$ & $573 \pm 11.02^{\mathrm{b}}$ & $1360 \pm 16.07^{\mathrm{a}}$ \\
\hline $\mathbf{F e}$ & $4.87 \pm 0.034^{\mathrm{a}}$ & $3.83 \pm 0.045^{\mathrm{b}}$ \\
\hline $\mathbf{P b}$ & $0.37 \pm 0.011^{\mathrm{a}}$ & $0.34 \pm 0.011^{\mathrm{a}}$ \\
\hline
\end{tabular}

and $b$ Means in the same row followed by different letters are significantly different $(p<0.05)$.

Table 4 shows the content of $\mathrm{Ca}, \mathrm{P}, \mathrm{Na}, \mathrm{K}, \mathrm{Fe}$ and $\mathrm{Pb}$ in the ash (p.p.m.) of camel and sheep "ossimi" milks. The levels of $\mathrm{Ca}, \mathrm{P}$ and $\mathrm{K}$ in the sheep "ossimi" milk ash were significantly higher $(P<0.05)$ than those in the camel milk ash, while, the level of $\mathrm{Na}$ and $\mathrm{Fe}$ in the camel's milk ash were significantly higher $(P<0.05)$ than those in the sheep "ossimi" milk ash. The most marked differences between the two types of milk, when the mineral 
composition is expressed in terms of the quantities present in a given volume of milk, are due to the different amounts of total solids in the two types of milk, as commented previously. These results were agreement with that previously reported (Abu-Lehia, 1987; Aderson, 1991 and El-Agamy et al., 1998).

These results were similar to those obtained by (AI-Wabel, 2008) who found that sheep milk had the highest content of the most minerals investigated. There were no significant differences $(p>0.05)$ in the concentrations of iron between sheep and camels milk. Camels have significantly higher concentration of copper in milk compared to sheep. There were significant differences in the concentration of calcium in milk $(p<0.05)$ between the two species. Camels have the highest concentration $(p<0.05)$ of sodium and potassium compared to two species.

The value of milk iron content is comparable to the data reported by (Gorban and Izzeldin, 1997). Multivariate analysis of variance showed that, as a set, mineral treatment affected milk mineral content. Few data are available on mineral composition of camels' milk. Dell' Orto et al., (2000) reported that salt composition of milk is influenced by factors such as health status of the udder and stage of lactation. In a study of (Gorban \& Izzeldin, 1997) have reported that the levels of sodium, potassium, phosphorus and zinc were higher, and those of iron and manganese markedly higher in milk of Arabian camels. Other authors observed that the contents of magnesium, iron, copper, manganese were greater in camel's milk (Abu-Lehia, 1987).

\section{REFERENCES}

Abu-Lehia, I.H.(1987). Composition of Camel Milk. Milchwissenchaft, 42: 368371.

Ackman, R. G. (1972). The analysis of fatty acids and related materials by gas liquid chromatography. In Progress in the Chemistry of Fats and other lipids., Vol. 12, R. T. Holman (Ed.). Pergamon Press, Oxoford, UK.

Aderson, R. R. (1991). Comparison of minerals in milk of four species. Comparative Biochemistry \& Physiology. A Comparative Physiology, 100(4): 1045 - 1048.

Aggarwala, A. C. and Sharma, R. M. (1961). A Laboratory Manual of Milk Inspection. $4^{\text {th }}$ edition. Asian Publishing House, Bombay.

Agrawal, R. P., Swami, S. C., Beniwal, R., Kochar, D. K., Sahani, M. S., Tuteja, F. C., Ghouri, S. K. (2003). Effect of camel milk on glycemic control, risk factors and diabetes quality of life in type-1 diabetes: a randomised prospective controlled study. J. Camel Practice \& Res., 10: $45-50$.

Ahmed, M. M. (1990). The analysis and quality of camel milk. Index of the thesis accepted for higher degrees by the Universities of Great Britain and Ireland and the Councils for National Academic Awards, 38: 1356

Al-Wabel, N. A. (2008). Mineral Contents of Milk of Cattle, Camels, Goats and Sheep in the Central Region of Saudi Arabia .Asian J. Biochem., 3 (6): $373-375$. 
AOAC. Association of Official Agriculture Chemists (1995). Official Methods of Analysis. $10^{\text {th }}$ ed. Published by the AOAC, Washington, D.C., USA.

Dell' Orto, V., Cattaneo, D., Beretta, E., Baldi, A. and Savoini, G. (2000). Efects of trace element supplementation on milk yield and composition in camels. Inter. Dairy J., 10: $873-879$.

El-Agamy, E. I., Abou-Shloue, Z. I. and Abdel-Kader, Y. I. (1998). Gel electrophoresis of proteins, physicochemical characterization and vitamin C content of milk of different species. Alex. J. Agric. Res., 43(2): $57-70$.

El-Agamy, E. I. (2006). Camel milk. In: Handbook of milk of non-bovine mammals. Park YW, Haenlein GF (Eds), Blackwell Publishing, lowa, USA, $297-344$

EL-Saied, U. M., Carriedo, I. J. A. and San Primitivo, F. (1998). Heritability of Test Day Somatic Cell Counts and Its Relationship with Milk Yield and Protein Percentage in Dairy Ewes. J. Dairy Sci., 81(11):2956 - 2961.

Farah, Z. (1993). Composition and characteristics of camel milk. J. Dairy Res., 60: 603 - 626 .

Fiske, C. H. and Subbarow, Y. (1925). The Colorimetric Determination of Phosphorus. J. Biol. Chem., 66: $375-400$.

Gomez-Cortes P.; Frutos P.; Mantecon, A. R.; Juarez, M.; De la Fuente, M.A. and Hervas, G. (2008). Milk production, conjugated linoleic acid content, and in vitro ruminal fermentation in response to high levels of soybean oil in dairy ewe diet. J. Dairy Sci., 91: 1560 - 1569.

Gorban, A. M. S. and Izzeldin, O. M. (1997). Mineral content of camel milk and colostrum. J. Dairy Res., 64: $471-474$.

Haenlein, G. F. W. (2001). The nutritional value of sheep milk. Intern. J. Anim. Sci., 16: $253-268$.

Hassan, A. H., Hagrass, A. I., Soryal, K. A. and El-Shabrawy, S. A. (1987). Physico-chemical properties of camel milk during lactation period in Egypt. Egypt. J. Food Sci., 15 (1): 1 - 14.

Hassan, H. A. (1994). Effects of crossing and environmental factors on production and some constituents of milk in Ossimi and Saidi sheep and their crosses with Chios. Small Rum. Res., 18(2): 165 - 172.

Hashim, I. B. (2002). Acceptance of camel milk among elementary school students in Al Ain city, Emir. J. Agric. Sci. 14: 54 - 59.

Hinrichs, J. (2004). Mediterranean milk and milk products. Review. Eur J Nutr., 43 (1): $12-17$.

Jandal, J. M. (1996). Comparative aspects of goat and sheep milk. Small Rum. Res., 22: 177 - 185.

James, C. S. (1995). Determination of the fat content of Dairy Products by the Gerber Method. In Analytical Chemistry of Food. Ed. Chapman and Hall., Glascow, U.K, PP: 93 - 95.

Khaskheli, M., Arian, M. A., Chaudhry, S., Soomro, A. H. and Qureshi, T. A. (2005). Physico-Chemical Quality of Camel Milk. J. Agri. Soc. Sci., 1(2):164 - 166.

Kirk, S. R. and Sawyer, R. (1991). Pearsons Composition Analysis of Food. Awl Harlow England. 
Konuspayeva, G.; Lemarie, E.; Faye, B.; Loiseau, G. and Montet, D. (2008). Fatty acid and cholesterol composition of camel's (Camelus bactrianus, Camelus dromedarius and hybrids) milk in Kazakhstan. Dairy Sci. Technol., 88: 327-340.

Magjeed, N. A., (2005). Corrective effect of milk camel on some cancer biomarkers in blood of rats intoxicated with aflatoxin B1. J. Saudi Chem. Society, 9 (2): $253-263$.

Miocinovic, D.; Kasalica, A. and Derovski, J. M. (2007). Impact of crossing of svrljic pramenka with east friesian sheep on change in milk protein content. Biotechnology in Animal Husbandry, 23 (5-6): 153 - 161.

Omer, R. H. and Eltinay, A. H. (2009). Changes in chemical composition of camel's raw milk during Storage. Pakistan. J. Nutr., 8 (5): $607-610$.

S. A. S. (1998). Statistical Analysis System User, Guide: Basis. SAS Inst. Inc Cary. NC.

Sendra, E., M. Capellas, M. Mor-mur, R. Pla, and B. Guamis. (2002). Temperature fluctuations during frozen storage of semi-hard ovine cheese. Milchwissenchaft, 57:322-324.

Shabo, Y., Barzel, R., Margoulis, M., Yagil, R., (2005). Camel milk for food allergies in children. Immunology and Allergy, 7: 796-798.

Shamsia, S. M. (2009). Nutritional and therapeutic properties of camel and human milks. Inter. J. Genetics \& Molecular Bio., 1(2): 52 - 58.

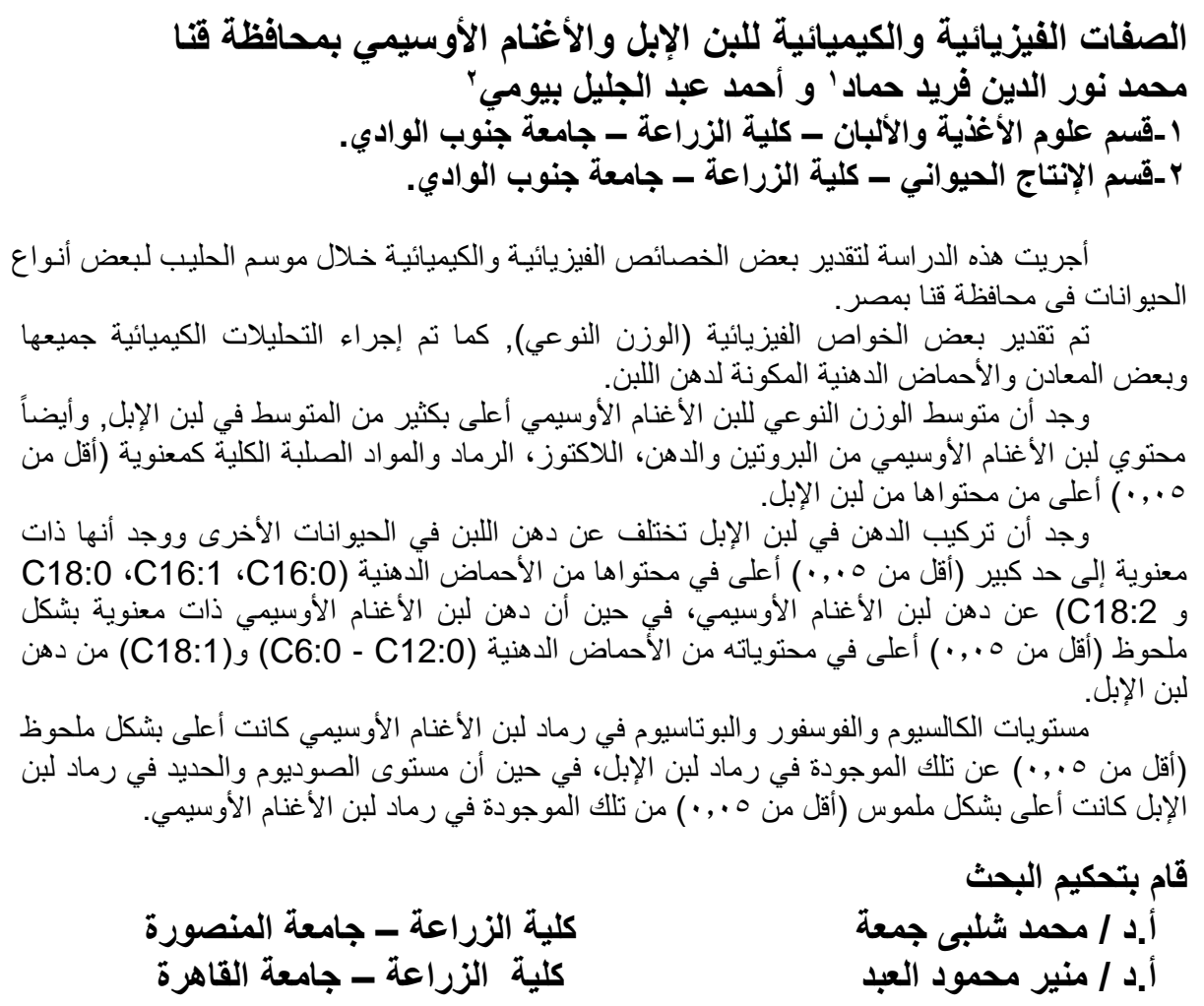

